\title{
Performance of Brazilian Companies: Year Effects, Line of Business and Individual Firms
}

\author{
Luiz Artur Ledur Brito* \\ E-mail address: 1lbrito@uol.com.br \\ Escola de Administração de Empresas de São Paulo - Fundação Getúlio Vargas \\ São Paulo, SP, Brazil \\ Flávio Carvalho de Vasconcelos \\ E-mail address: fvasconcelos@fgvsp.br \\ Escola de Administração de Empresas de São Paulo - Fundação Getúlio Vargas \\ São Paulo, SP, Brazil
}

\begin{abstract}
Performance varies. This simple statement conceals many intricacies of strategic management. Because performance varies among individual firms, researchers can explore factors that differentiate these firms and explain why some firms are consistently outperforming others. Because performance varies among industries, researchers can explore structural characteristics of different branches of accounting as a source of explanation. Because performance varies with time, researchers can explore environmental and internal dynamic elements that drive strategic decision-making. In reality, measuring and analyzing performance is a very complicated issue when performance varies simultaneously from firm to firm, from industry to industry and from year to year. The theoretical discussion behind this question is the relative importance of the industrial organization derived approach to strategy versus the resource-based view. This paper analyzes the composition of performance variance of a set of Brazilian firms from 1998 to 2001. The results demonstrate that firm effects are still dominant, with year and industry effects being lower, as previous studies with North American firms have indicated.
\end{abstract}

Key words: performance; strategy; variance components; Brazilian firms.

Received 05 November 2003; received in revised form 28 January 2004.

Copyright (C) 2004 Brazilian Administration Review. All rights reserved, including rights for translation. Parts of this work may be quoted without prior knowledge on the condition that the source is identified.

\footnotetext{
* Corresponding author: Luiz Artur Ledur Brito

Av. Nove de Julho, 2029, São Paulo, SP, 01313-902, Brazil.

Tel.: +55 113281 7780; fax: +55 1132817780 .
} 


\section{INTRODUCTION}

If a researcher observes a set of companies over a period of time, he will notice that there is a distribution of performance results that looks something like a normal curve. Some firms will have higher sustainable performance - the empiric definition of competitive advantage (BARNEY, 2002) and some will have poorer results which, if they are persistent, will lead to the company being eliminated as a market force.

The attempt to answer why some firms outdo others over time is a question that lies at the heart of strategy. Companies differ among themselves for a number of reasons: size, product, people, location, organisation and history. These differences end up reflecting on the variance in performance. Strategies must be able to understand and explain this variance (WALKER, 2004, p. 3).

Neo-classical economic theory originally focused on results which were grouped from lines of business as a whole as a primary explanation for heterogeneity rather than individual differences. This approach places individual differences between companies in the background. Although the approach recognised that firms are different, its interpretation implicitly accepts, as do the majority of economic approaches, that these differences are also determined by the context, leading to the idea that the best form of analysis is by line of business and not individual firms (NELSON, 1991). The field of strategy has taken an entirely opposite approach, basing itself on the premise that individual actions and positions cause relevant differences and therefore the most suitable analysis is the company itself and not the line of business (RUMELT, 1991).

The matter of heterogeneity and homogeneity is what determines the analysis unit of a field of research (KLEIN; DANSEREAU; HALL, 1994). The economic approach assumes heterogeneity between lines of business to be more important while the field of strategy sees heterogeneity between different firms as being more relevant.

This debate has expanded within the field of strategy itself, especially through the originating line in the field of industrial organisation and the structure-behaviour-performance model. The structure of the market in a line of business determines the behaviour of companies which in turn determines their performance. This was the theoretical basis of the development of Michael Porter's positioning concepts. In this approach the business is of great relevance when evaluating and interpreting the performance of companies (PORTER, 1981).

Another approach places emphasis on the internal resources of an organisation and its origins are found in the early classics such as Barnard (1938), Selznick (1957) and Penrose (1959). Based on strategic resources, the view focuses on individual differences between companies as a base for the development of strategy (BARNEY, 1991, 2001; CONNER, 1991; PETERAF, 1993; WERNERFELT, 1984, 1995). These researchers concentrate their interest on understanding the "black box" of companies, their internal workings, and argue that the continued success of a firm is a function of the firm's unique competitive resources (HOSKISSON, 1999).

Although the analysis of the dispersion of performance results is fundamental to any area of administration, the theme has received relatively little attention to date and has been the object of a limited number of empirical papers, probably reflecting the difficulties of data and statistical analysis (McGAHAN; PORTER 1997). Rumelt (1991) presented the most influential study, developing further the initial approach of Schmalensee (1985). McGahan \& Porter $(1997,2002)$ broadened the scope of Rumelt (1991) using a more far-reaching set of data and a more sophisticated analysis approach. The theme continues today. In 2003, several articles related to the subject were published in the main strategic periodical, the Strategic Management Journal (ADNER; HELFAT, 2003; HAWAWINI; SUBRAMANIAN; VERDIN, 2003; RUEFLI; WIGGINS, 2003; McNAMARA; VAALER; DEVERS, 2003). Very few studies have been done outside the United States using data from non-American economies. Claver, Molina \& Tari (2002) published a study analysing Spanish companies, finding 
results similar to American studies. The effect of the individual company was shown to be a dominating, with very little influence from the line of business and the year. Khanna \& Rivkin (2001) analysed the corporative effect in a wider sample of business groups in several developing economies around the world, reaching the conclusion that the composition of performance variance (the percentage of variance associated to each type of effect) may vary in a very significant way. Therefore, great care must be taken when transferring conclusions developed from other competitive environments.

The aim of this paper is to assess the dispersion of performance results of Brazilian companies and compare the composition of the variance of this performance with the results found in the American environment. Previous studies have indicated the individual company as the main source of performance variation. For instance, McGahan \& Porter (1997), analysing data from companies in the manufacturing industry, demonstrated that idiosyncratic factors pertaining to the firm were responsible for $35.45 \%$ of total variance. The line of business which the company is involved in had a smaller influence of $10.81 \%$. Macroeconomic factors that vary from year to year, the year effect, accounted for only $2.34 \%$. This paper analysed the dispersion of performance of 292 companies operating in Brazil from 1998-2001 and assessed the composition of the performance variance measured as operational profit on total assets. The results show that the year effect is surprisingly small and the effect associated with the line of business is lower than results obtained in previous research. The individual company is the dominating explanation in the dispersion of performance.

The following section presents a detailed review of previous studies into the components of performance variance in strategy. The basic statistic of the variance component method and the characteristics of the analysed sample are discussed afterwards. The presentation of results and their discussion are then dealt with and the conclusions reached by the study bring the article to a close.

\section{ANTECEDENTS}

Schmalensee (1985) published the first paper analysing the components of performance variance using Federal Trade Commission data from 1975. In the paper, 1775 business units, operating in 242 lines of business, were analysed. The business units belonged to 456 corporations. Operational profits and total assets were taken as the financial indicator of performance. The median was $13.6 \%$ and the standard deviation was $18.7 \%$. The market share of each business unit was used in an attempt to find specific factors of the business unit that could affect profitability. Market share had been identified beforehand as being highly influential and positive in the profitability of a business (Ravenscraft, 1983). Schmalensee (1985) analysed the data using analysis techniques of variance and components of variance, arriving at the following main conclusions:

- There is no significant influence on results of a business unit which can be linked to the fact that the unit belongs to a larger corporation.

. The line of business that a unit operates in has a sizeable influence on its results and accounts for 19$20 \%$ of total variance.

. Market share accounts for a very small percentage of variance in the results of business units.

Around $80 \%$ of total variance cannot be accounted for by the factors outlined above.

The fact that the influence of the line of business had been clearly identified and held statistical significance was seen, in Schmalensee's opinion, as a justification for the classic strategy approach focusing on the line of business. One of the most important points of the research, however, lay in what was not explained. Recognising that the model proposed could not account for over $80 \%$ of the variance observed in profitability of the business units, the author states: Despite the differences 
between lines of business being important, they clearly do not represent all that matters (paraphrasing of SCHMALENSEE, 1985, page 350).

Rumelt (1991) considerably expanded the original work of Schmalensee (1985) using the same FTC data base, but including the results of four years instead of only one. He used the results from 19741977. Using practically the same sample of 1774 business units and four years of results, he had 6932 observations using the same criterion for measuring performance, the operational profit per total assets. The median value was $13.9 \%$ and the standard deviation was $16.7 \%$, values similar to those found by Schmalensee (1985). Having four observations for each business unit allowed him to isolate the amount of variance associated with the individual business unit in a direct way instead of the attempt to connect it to another variable such as the market share, as had been done by Schmalensee (1985). It was also possible to calculate the variance linked to interaction between the year and line of business by separating the influence of the line of business in a fixed component and a transient component (the interaction between the year and line of business). The proposed model could be used to account for over $63 \%$ of total variance. The main conclusions of the work of Rumelt (1991) may be summarised as follows:

- Confirming the finding of Schmalensee (1985), no significant effect in variance of results can be linked to the fact that the business unit belongs to a larger corporation.

The line of business has a significant influence and meaning in the dispersion of results of business units and accounts for $16.2 \%$ of total variance. Approximately half of this value is linked to fixed effects of the line of business that are found in every year analysed and the other half is linked to transient effects that influence all members of a line of business in particular in specific years.

. The time or year factor, in an isolated way, did not account for any significant part of total variance. Its influence would only manifest in the interaction with the line of business factor mentioned beforehand. This isolated factor of time or year, should capture the set of macroeconomic influences that affect all business units in a single year in the same way.

Idiosyncratic factors which are linked to the individual business units are persistent throughout the whole period analysed account for $46.4 \%$ of total variance. This indicates market share, as used by Schmalensee (1985), to be a poor indicator of the individual effects of business units. A large portion of this variance was not picked up in the Schmalensee (1985) model and ended up accounting for a significant chunk of the $80 \%$ total variance not being accounted for. In the model used by Rumelt (1991) only 36.9\% of total variance remains unaccounted for.

Roquebert, Philips \& Westfall (1986) published similar research using a broader and more recent data base called Compustat. The data covered the period of 1985-1991, and the analysis was carried out with 16596 observations. The Compustat data base covered: 746 lines of business, while the FTC covered only 260; over three thousand corporations against FTC's 500 or less. It was also less restrictive, including smaller corporations and with a lower number of business units. The analysis also made use of the variance components technique, this time estimated by the maximum probability method. The conclusions were quite similar to previous studies, with one notable exception: the corporation effect. The authors found a significant corporation effect, accounting for $17.9 \%$ of total variance, whereas the two previous studies had not identified any significant effects associated with corporations. The line of business accounted for $12.5 \%$ of total variance $(2.3 \%$ corresponding to yearline interaction and therefore transient) and the business unit was, once again, responsible for the greater part of the variance, accounting for $37.1 \%$. The model accounted for $68.0 \%$ of total variance, leaving $32.0 \%$ unaccounted for.

The presence of the corporation effect seemed to be very sensitive to the choice of sample, increasing as the number of business units per corporation was reduced. This seemed to be in the same trend as Rumelt's (1991) finding in sample B when he found a small corporation effect. Other authors have dealt with the theme of corporation effect in greater detail (BRUSH; BROMILEY, 1997; 
BRUSH; BROMILEY; HENDRICKX, 1999; CHANG; SINGH, 2000; BOWMAN; HELFAT, 2001; KHANNA; RIVKIN, 2001; McNAMARA; VAALER; DEVERS, 2003).

McGahan \& Porter (1997) published a broad study, also based on Compustat data, covering the period of 1981-1994. The set of data analysed constituted 72742 observations with an average of 5196 business units per year throughout fourteen years of analysis, a substantially higher number than data used in any previous study. The study also included companies of a diverse nature, pertaining to other economic sectors outside of manufacturing. The other economic sectors that were analysed were: minerals and agriculture, retail, transport, services, hotels and entertainment. Each of these broad sectors encompassed several lines of business (defined as the SIC four-digit classification). The analysis was done by economic sector in an isolated way, so the results of the manufacturing sector can be compared to previous studies. The analysis method was similar to that used by Rumelt (1991) using the analysis of variance components followed by a variance analysis itself. The biggest difference introduced into the method was the consideration of serial correlation in the margin of error, trying to detect the influence of shocks in the previous year affecting the year in question.

The variance composition was quite different in the several economic sectors considered. While the manufacturing sector showed results which were quite similar to previous studies, other sectors showed different compositions, generally with greater participation in the line of business in detriment of the business unit.

In the economic sector of manufacturing, the main results found were:

The largest component of total variance was that linked to the individual business unit, representing $35,45 \%$ of total variance. The effect of the longest time frame since Rumelt (1991) must be taken into account here. Only those effects which were present throughout the period in question and linked to the individual business unit were detected. Changes that were made to these factors during the period ended up deviating part of the dispersion to the margin of error.

The line of business accounted for $10,81 \%$ of total variance.

The year effect, representing the impact of macroeconomic factors affecting the business units in specific years, accounted for $2,34 \%$ of total variance.

A negative co-variance of $2,27 \%$ between corporation and line of business was identified. Rumelt (1991) had found a very small value, but a value which was positive to this co-variance and decided to set it at zero in the final presentation of results. The interpretation of this co-variance is that the corporation could have an influence on the selection of lines of business in which it had a stake.

- The model accounted for only $46,30 \%$ of total variance, so that the error margin was greater than in the study of Rumelt (1991) and Roquebert, Philips \& Westfall (1996).

The data were also analysed using the model proposed by Rumelt (1991), arriving at comparable results. In the other economic sectors analysed besides manufacturing, the influence of the line of business was much greater, so that when the data gathered were analysed, the line of business accounted for $17 \%$ of total variance. In hotels and entertainment, the line of business accounted for $64.3 \%$ of total variance and $47.37 \%$ in the service industry. Manufacturing, as the authors point out, was an oulier, with the line of business accounting for only $10.81 \%$ of total variance (McGAHAN; PORTER, 1997, p. 26). Unfortunately, much of the discussion and debate was done using the data collected comparing them to previous studies which focused exclusively on this outlier of manufacturing. The convergence of results was not evident as demonstrated in the more detailed analysis developed above.

Table 1 shows a comparison of results of these studies for the manufacturing sector. Despite the discrepancy related to the corporation effect in the study of Roquebert, Philips \& Westfall (1996), the results showed notable convergence given the different sets of data and methods. The major variance component has always been the individual business unit, being responsible for about a third to half of 
total variance. The line of business accounted for a significant part of total variance, from $10 \%$ to $20 \%$, a part of this value being due to interaction with the year factor. The year factor, when detected, accounted for a small part of total variance (no more than 2-3\%).

Table 1: Comparative Summary of Previous Studies into the Composition of Performance Variance (Manufacturing Industries)

\begin{tabular}{|l|c|c|c|c|c|}
\hline \multicolumn{1}{|c|}{ Year } & $\begin{array}{c}\text { Schmalensee } \\
(1985)\end{array}$ & $\begin{array}{c}\text { Rumelt } \\
(1991)\end{array}$ & $\begin{array}{c}\text { Roquebert et } \\
\text { al. (1996) }\end{array}$ & $\begin{array}{c}\text { McGahan e } \\
\text { Porter (1997), } \\
\text { with Rumelt } \\
\text { model }\end{array}$ & $\begin{array}{c}\text { McGahan \& } \\
\text { Porter (1997) }\end{array}$ \\
\hline Line of business v year & N/A & $0 \%$ & $0.5 \%$ & $0.40 \%$ & $2.34 \%$ \\
\hline Fixed line of business & N/A & $7.84 \%$ & $2.3 \%$ & $4.44 \%$ & N/A \\
\hline Line of business, total & $19.59 \%$ & $16.16 \%$ & $12.5 \%$ & $11.64 \%$ & $10.81 \%$ \\
\hline Corporation & & $0.80 \%$ & $17.9 \%$ & $2.05 \%$ & N/A \\
\hline $\begin{array}{l}\text { Co-variance }- \text { line of } \\
\text { business }\end{array}$ & $-0.62 \%$ & $0 \%$ & N/A & $-1.42 \%$ & $-2.27 \%$ \\
\hline Market share & $0.62 \%$ & N/A & N/A & N/A & N/A \\
\hline Business unit & N/A & $46.37 \%$ & $37.1 \%$ & $33.79 \%$ & $35.45 \%$ \\
\hline Model & $19.59 \%$ & $63.33 \%$ & $68.0 \%$ & $46.46 \%$ & $46.33 \%$ \\
\hline Variance unaccounted for & $80.41 \%$ & $36.67 \%$ & $32.0 \%$ & $53.54 \%$ & $53.67 \%$ \\
\hline
\end{tabular}

Source: MCGAHAN; PORTER, 1997; ROQUEBERT; PHILLIPS; WESTFALL, 1996; RUMELT, 1991; SCHMALENSEE, 1985.

Other authors have also explored the theme using different methodologies and approaches, but reaching results which were consistent with the summary shown in previous studies. Wernerfelt \& Montgomery (1988) used Tobin's Q ratio to measure performance, reaching conclusions similar to those of Schmalensee (1985). Hansen \& Wernerfelt (1989) decomposed the rates of profitability in economic components and organisations, concluding that both models are significant and proposed an integrated model with greater explanatory power than isolated models. Powell (1996), using a methodology of questionnaires and interviews, examined the perception of executives and confirmed that the factors associated to the line of business could account for $20 \%$ of total variance. Mauri \& Michaels (1988), using a smaller sample from the Compustat base found that the fact of belonging to a certain line of business could account for a small part of total variance. Nevertheless, the line of business greatly influenced the choice of strategies of business units which were operationalised such as R\&D and investment in publicity and advertising. McGahan (1999), using the same data as McGahan \& Porter (1997) but with a different methodology, explored the composition of performance variance measured with different metrics (Tobin's Q ration, traditional bookkeeping profitability and a hybrid measurement - the return on the replacement of assets). The conclusions also confirmed that the effects of the business unit were more important than the effect of the line of business, but indicated that the latter were more permanent and predictable. McGahan \& Porter (1999) explored the persistence of various effects, finding that the line of business effect showed greater persistence than the others. Hawawini, Subramanian \& Verdin (2003) also looked at other value-based performance measures. The results with the different performance measurements turned out to be quite similar. McNamara, Vaaler \& Devers (2003) used the Compustat base for an analysis of seventeen four-year windows covering the period of 1978 to 1997 and checking the dynamic of alteration of variance composition throughout this period. The influence of the line of business seems to fall over time, reaching only $3.5 \%$ in the last window from 1994-1997, while the corporation effect increases at the same rate. The business unit, however, continues to be the largest source of variance in the model.

Almost all previous studies made use of data from companies in the American economy. Claver, Molina \& Tari (2002) analysed 679 Spanish companies from 1994-1998, finding a similar variance composition with $42.69 \%$ of total variance attributed to the company or business unit and only $4.84 \%$ to the line of business. The year effect was once again too small, at $0.36 \%$. Khanna \& Rivkin (2001), 
analysing a wide-ranging sample of business groups in developing countries, found a significant influence of association to a determined group and observed different variance compositions from country to country, highlighting the influence of institutional context on this composition. Brito \& Vasconcelos (2003) analysed the variance composition of the wide-ranging Compustat Global database that included 12542 companies, operating in 78 countries from 1998 - 2001, with a total of 60092 observations. The analysis proposed the inclusion of a new type of effect, the country effect which collects the variation associated to the fact that all the companies were located in a certain country and also covered several sectors outside of manufacturing. The results confirmed that the variance composition shows huge differences between economic segments and that the country effect does indeed exist and is approximately as important as the line of business effect, but that the main variance component is the individual company or business unit.

\section{Methodology AND DATA}

The availability of trustworthy data is one of the major difficulties in carrying out this type of study. This paper made use of data published in the Yearly Balance of the Gazeta Mercantil newspaper from 1998-2001. The newspaper gathers performance data from Brazilian companies and international companies operating in Brazil. Fifteen lines of business were selected whose activity diversified very little and were very concentrated, thereby avoiding the problem of including companies with multiple business units and with consolidated results pertaining to the main line of business. Therefore, it was not possible to measure the corporation effect as the data available dealt with the company as a whole. Only companies with a turnover upwards of $\mathrm{R} \$ 10$ million in 2001 were considered. As the classification had been slightly altered over the years, 2001 was taken as the base year and the other years were adjusted accordingly. In all, 252 companies were selected, which allowed for 938 observations during the period.

Operational profit divided by total assets was used as a performance indicator, making the study comparable to previous studies and avoiding some of the fluctuations owing to financial components. The analysis was also repeated with other indicators such as net profit by total assets with similar results. Initially, a descriptive analysis of data was done followed by the application of the methodology of variance components. The basic model for variance components can be shown by this equation: .

$r_{i, k, t}=\mu+\gamma_{t}+\alpha_{i}+\delta_{i t}+\phi_{k}+\varepsilon_{i, k, t}$

where the indices:

$i$ : $\quad$ represents the various industrial sectors analysed.

$\mathrm{k}$ : represents the individual firms.

$\mathrm{t}$ : represents the years considered in the study.

And the variables:

$r: \quad$ is the relation between operational profit and total assets

$\mu: \quad$ is the general median of this relation for all companies in the sample.

$\alpha: \quad$ is the line of business effect.

$\gamma: \quad$ is the year effect.

$\delta: \quad$ is the interaction between the line of business and the year 
$\phi: \quad$ is the firm effect.
$\varepsilon: \quad$ is what is left over, not accounted for by the model.

The line of business effect gathers sources of variation that affect all participant of a certain line of business independent from other factors. The differences between the other $\alpha_{i}$ values reflect the differences in the competitive environments such as: entry conditions, conditions of demand and capacity, varying levels of risk, varying levels of utilisation of capacity, technological changes that affect the line of business as a whole. The year effect includes the set of macroeconomic values that affect all the companies in a certain year. Nationwide or worldwide crises, periods of depression or growth, for instance, cause the different values that can be assumed by the $\gamma_{\text {t.. }}$ The interaction effect between the line of business and the year detects the variation that is specific to some lines of business in certain years. A currency devaluation that affects only a few lines of business in certain years would be expected to show up here. Finally, the firm effect detects systematic factors, linked idiosyncratically to each specific firm, which influence the results of this company in all the years analysed. Here specific abilities in running a business, reputation and patents can be included.

Assuming that the different factors of the basic model are independent, the variance of the dependent variable, operational profit over total assets, can therefore be expressed by the following equation:

$\sigma_{r}^{2}=\sigma_{\gamma}^{2}+\sigma_{\alpha}^{2}+\sigma_{\delta}^{2}+\sigma_{\phi}^{2}+\sigma_{\varepsilon}^{2}$

In the case of non independence of some factors, the terms of co-variance should be included as was done by Rumelt (1991) in the case of co-variance between the corporation and line of business, recognising that corporations have an influence over the choice of lines of business in which they participate.

The traditional estimative method of variance components is the solution of the system of equations equalling the values obtained for the sum of the median squares. With the equation of their expected value and resolving with the resulting system of equations. Rumelt (1991, p. 174-176) offers a didactic example of this calculation for a simple case of variance composition of measured performance as operational profit over assets. This method is known as the ANOVA method and was already firmly established in 1934 (SEARLE; CASELLA; McCULLOCH, 1992). The problem of estimating by the ANOVA method is that it does not eliminate the possibility of obliquity in the estimate and they can be negative, which makes no physical sense since variances, by definition, are positive. From 1950 onwards, there were many important developments in methodology already established, mainly in the treatment of non-balanced data that culminated in the establishment of new methods based on maximum probability criteria and minimal norms.

The estimate of variance components by the method of maximum probability demands that some distribution should be attributed to the data. Up until now, the estimate of maximum probability components is based in premises of normalcy. The solution to this problem requires the use of interactive processes since the equations cannot be resolved analytically. The central idea is to maximise the part of the probability that does not suffer variation with the parameters of the model, i.e. fixed effects. The maximum probability (MP) and restricted maximum possibility (RMP) techniques have become the preferred estimate methods, especially in the cases of unbalanced data (SEARLE; CASELLA; McCULLOCH, 1992). Another estimative method that does not require interactive process is MINQUE (Minimum Norm Quadratic Unbiased Equation). This method does not require a determined distribution of random effects or of margin of error. Nor does the method involve interactions. The estimates are, however, a function of the values used a priori. The minimal property is applied only to these a priori values. Nevertheless, whatever the a priori values, the estimates do not suffer from obliquity (SEARLE; CASELLA; McCULLOCH, 1992).

As the variance components technique outlined above does not allow for an elastic significance test of each component, a nested ANOVA test was used in sequence which made use of a regression with 
dummy variables introduced sequentially and using the $\mathrm{F}$ statistic to test the increase in variance accounted for by the introduction of the last group of variables.

\section{RESULTS AND DISCUSSION}

The first analysis approach is a purely descriptive view of the heterogeneity of performance. Table 2 shows these data and allows us to assess them.

Table 1: Descriptive Analysis of Data, Brazilian Companies, 1998-2001

\begin{tabular}{|l|c|c|c|c|c|c|c|}
\hline Line of Business & Observations & Average & Minimum & Maximum & $\begin{array}{c}\text { Standard } \\
\text { Deviation }\end{array}$ & Asymmetry & Kurtosis \\
\hline Petroleum Derivates & 39 & 11.3 & -5.9 & 47.8 & 12.5 & 0.97 & 0.94 \\
\hline Steel & 58 & -0.5 & -34.8 & 10.5 & 7.8 & -1.70 & 5.50 \\
\hline Petrochemical Products & 200 & 3.8 & -42.0 & 48.8 & 12.8 & 0.31 & 1.78 \\
\hline Fertilisers & 85 & 2.1 & -64.6 & 32.6 & 13.6 & -1.70 & 6.90 \\
\hline Glass products & 30 & 7.7 & -2.3 & 24.6 & 8.3 & 0.73 & -0.72 \\
\hline Car Parts & 95 & 2.3 & -40.3 & 66.3 & 15.7 & 0.89 & 3.42 \\
\hline Electrical Goods & 41 & -4.0 & -57.3 & 15.7 & 14.4 & -1.71 & 4.14 \\
\hline $\begin{array}{l}\text { Agricultural Equipment } \\
\text { \& Machinery }\end{array}$ & 60 & -0.2 & -43.4 & 35.7 & 14.2 & 0.01 & 1.38 \\
\hline Textile (household) & 34 & 1.5 & -36.0 & 13.0 & 8.9 & -2.92 & 10.51 \\
\hline Electric Conductors & 18 & -5.2 & -66.7 & 8.1 & 18.0 & -2.70 & 8.20 \\
\hline Toiletries & 25 & 7.5 & -15.9 & 36.8 & 13.2 & 0.49 & 0.42 \\
\hline Leather Goods & 34 & 9.4 & -10.0 & 96.1 & 17.3 & 4.02 & 19.82 \\
\hline Furniture & 53 & 5.7 & -4.7 & 33.4 & 8.7 & 1.29 & 0.95 \\
\hline Pharmaceuticals & 117 & 9.3 & -43.2 & 55.8 & 17.1 & 0.12 & 0.45 \\
\hline Ceramics & 49 & 0.2 & -13.2 & 31.9 & 8.0 & 1.46 & 4.40 \\
\hline & 938 & 3.8 & -66.7 & 96.1 & 13.9 & 0.28 & 5.03 \\
\hline
\end{tabular}

Source: analysis by the authors.

The average of $3.8 \%$ operational profit over total assets is a low value which reflects the performance of Brazilian companies during this period. The analysis of annual averages shows little variation, with $3 \%$ for $1998,2.9 \%$ for $1999,4.8 \%$ for 2000 and $4.1 \%$ in 2001 . The total standard deviation is somewhat lower than the $16.7 \%$ found by Rumelt (1991) and the $15.7 \%$ found by McGahan \& Porter (1997). The distribution is clearly different from a normal curve as shown by the coefficients of asymmetry and kurtosis.

Figure 1 shows a histogram of data plotted against a normal curve of the same median and standard deviation. The distribution is slightly asymmetrical and is of a leptokurtic nature as shown by the kurtosis coefficient being greater than 3. Intuitively, this indicates a distribution where there is simultaneously greater concentration around the median and greater presence of distant points in the median. The shoulders of the curve are ragged and the material removed has been added to the tails (SPANOS, 1999). The analysis of variance components was carried out as follows using various calculation methods. The results are shown in Table 3. 
Figure 1: Histogram of Sample

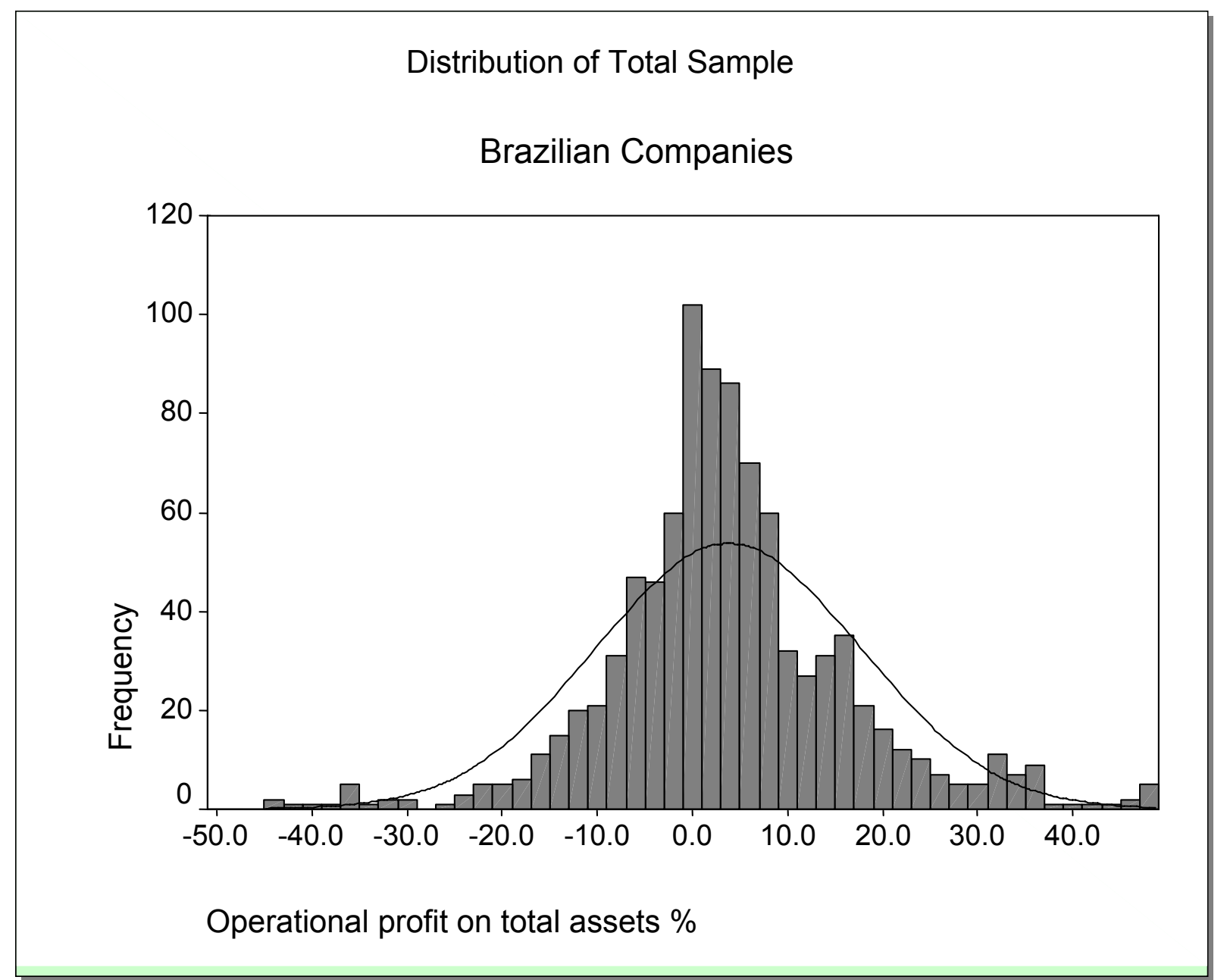

Source: data processed by the authors.

Table 2: Results of the Analysis of Variance Components

\begin{tabular}{|l|c|c|c|c|c|c|}
\hline & ANOVA & MIVQUE & $\begin{array}{c}\text { Maximum } \\
\text { Probability }\end{array}$ & ANOVA & MIVQUE & $\begin{array}{c}\text { Maximum } \\
\text { Probability }\end{array}$ \\
\hline Year & -0.1 & -0.1 & 0 & $0 \%$ & $0 \%$ & $0 \%$ \\
\hline Line of Business & 8.6 & 14.4 & 8.5 & $4.4 \%$ & $7.1 \%$ & $4.3 \%$ \\
\hline Year v Line Interaction & 5.6 & 4.2 & 4.8 & $2.9 \%$ & $2.1 \%$ & $2.4 \%$ \\
\hline Individual company & 102.4 & 106.4 & 107.3 & $52.7 \%$ & $52.3 \%$ & $54.0 \%$ \\
\hline Variance unaccounted for & 77.9 & 78.3 & 78.0 & $40.0 \%$ & $38.5 \%$ & $39.3 \%$ \\
\hline Total & 194.4 & 203.2 & 198.6 & $100.0 \%$ & $100.0 \%$ & $100.0 \%$ \\
\hline
\end{tabular}

Source: calculations by the authors.

When the variance composition is compared to the previous studies shown in Table 1, some aspects are worth noting. The turbulent environment of Brazil does not seem to have a significant effect on performance dispersion. This result confirms the findings of previous studies with American data carried out at different times. The major component of variance is, once again, the individual company. Variance linked to line of business accounts for under $10 \%$ of total variance by all methods of calculation. Finally, the model can account for around $60 \%$ of total variance, a value comparable to previous studies. 
In order to obtain some type of statistical significance test of the above effects, the data were analysed under the standard premises of the squared minimums method. Dummy variables were created to represent the year, line of business and individual company effects. Following the method used by Rumelt (1991) and McGahan \& Porter (1997), the nested ANOVA technique was used. The groups of dummy variables are introduced in a sequence and the percentage of variance variation is tested by an $\mathrm{F}$ test to assess the significance of the increase in explicative power by this group of variables. Owing to computational difficulties, this model is a more restrict version of equation (1) where the year-line of business interaction is not contemplated. The technique is sensitive to the order of introduction of the groups of variable because the variance which has already been explained by variables which were introduced beforehand is not considered in the test. To maximise the sensitivity of the year effects, the set of dummy variables corresponding to the year were introduced first, followed by the corresponding group for the line of business. In the final stage, the set corresponding to individual companies was introduced.

Table 4 shows the results.

Table 4: Significance of Regression Test

\begin{tabular}{|l|c|c|c|c|}
\hline & $\begin{array}{c}\text { Change in the } \\
\mathrm{R}^{2}\end{array}$ & $\begin{array}{c}\text { Change in the } \\
\mathrm{R}_{\mathrm{adj}}^{2}\end{array}$ & $\begin{array}{c}\text { Change in the F } \\
\text { statistic }\end{array}$ & $\begin{array}{c}\text { Significance of the change in the F statistic } \\
\text { (p-value) }\end{array}$ \\
\hline Year & $0.3 \%$ & $0.0 \%$ & 1.018 & 0.384 \\
\hline $\begin{array}{l}\text { Line of } \\
\text { Business }\end{array}$ & $8.3 \%$ & $6.9 \%$ & 5.932 & 0.000 \\
\hline Company & $60.0 \%$ & $50.1 \%$ & 5.546 & 0.000 \\
\hline $\begin{array}{l}\text { Complete } \\
\text { Model }\end{array}$ & $68.6 \%$ & $57.0 \%$ & 5.913 & 0.000 \\
\hline
\end{tabular}

Source: calculations by the authors.

Note: dummy variables referring to the year were introduced first, followed by corresponding variables of the line of business and variables corresponding to the individual companies were introduced last of all.

The year effect did not add power of explanation to the model, even as the first group of variables to be introduced. This finding is consistent with the previous analysis of variance components that indicated merely a variance caused by the year-line of business interaction. This interaction was not included in this type of test and the corresponding variance was absorbed by the effects of the line of business and isolated company. The line of business accounted for a limited part of the variance, leading to an $\mathrm{R}^{2}$ of only 0.083 despite being statistically significant owing to the large amount of data used in the regression. ( $p$-value $<0,001$ ). The introduction of the firm effects provoked the biggest change in the $\mathrm{R}^{2}$ taking it to 0.686 and was also clearly significant $(p$-value $=<0,001$ ).

\section{CONCLUSIONS}

The analysis of performance dispersion of Brazilian companies shows similar behaviour to that seen beforehand in studies carried out with American companies. The first aspect is to highlight the relevance of this dispersion. The standard deviation from performance distribution is estimated at $13.9 \%$. This number is of great managerial significance. A company which has a performance, an above-average standard performance would have a performance of over $15 \%$ of operational profit over assets, which has a relevant managerial impact when compared to a median of only $3.8 \%$. This indicates that superior performance is not a rare factor and emphasises the importance of the study of the heterogeneity of performance.

Companies differ for a number of reasons (NELSON, 1991; CARROLL, 1993), but studies into the composition of performance variance show that a great part of heterogeneity is permanent and remains 
year in year out affecting the company's results. This "firm effect" could account for between a third and a half of total observed variance. When it comes to Brazilian companies, this proportion was over $50 \%$ for all methods of evaluation. Factors pertaining to the line of business are also present. In the case of Brazilian companies, they were of less importance than in previous studies, accounting for only $4-7 \%$ of total variance. The part of total variance accounted for by the year factor was not detected in the Brazilian sample. No part of the dispersion seen in performance can be linked to this type of factor, not even in the apparently turbulent environment in which we live. This perceived turbulence does not systematically affect companies unless it is through the line of business, which accounts for around $2 \%$ of the total. The results suggest the importance of a strategy approach based on resources that focus specific characteristics to the firm itself. The combination of two approaches, as suggested by Wernerfelt (1995) seems to be the most complete form. The influence of the line of business, even of a lower percentage, remains significant and relevant. Furthermore, some effects seen as company-related effects, may be derived from a privileged position in the market and not from a resource (COOL; COSTA; DIERICKX, 2002). Even in the case of an approach derived from the tradition of the industrial organisation, the exploration of factors which may justify individual differences seems to be more important that the justifications of differences from one line of business to another.

Merely being in the right place to take advantage of certain economic shocks and situations involving rule changes has no solid statistical support. Excelling at what you do is still, maybe now more than ever, the best option.

This paper has several limitations. The first concerns the data, which are limited and do not include multi-divisional companies, and therefore many lines of business were not taken into consideration. The choice of performance indicator is a simple and crude estimate of the true concept of performance and other studies may explore the same approach using other indicators. Longer time frames may also be explored, but here there is the downside that they may not capture variations in the time of the competitive factors of the firm. Longer time frames therefore have a tendency to reduce the firm effect as only the median factors throughout the period are evaluated. Despite these restrictions, the study is the first analysis of this type using Brazilian data. It shows signs of convergence with studies in other countries and paves the way for future study in the field. Some possibilities for further research may be: the exploration of other wider data bases available in the country; models that include other types of effects such as geographical location; papers attempting to determine the value of effects for each company or line of business and not only the composition of variance; use of models that recognise the hierarchy and dependence of observations such as multi-level models.

\section{BIBLIOGRAPHY}

ADNER, R.; HELFAT, C. E. Corporate effects and dynamic managerial capabilities. Strategic Management Journal, v. 24, p. 1011 - 1025, 2003.

BARNARD, C. The Functions of the Executive, Cambridge MA, Harvard University Press, 1938.

BARNEY, J. Firm resources and sustained competitive advantage. Journal of Management, v. 17, n. 1, p. 99-120, 1991.

BARNEY, J. B. Resource-based theories of competitive advantage: a ten year retrospective on the resource-based view. Journal of Management, v. 27, p. 643-650, 2001.

BARNEY, J. Gaining and Sustaining Competitive Advantage, second edition, Upper Saddle River, NJ, Prentice-Hall, 2002. 
BOWMAN, E. H.; HELFAT, C.E. Does corporate strategy matter? Strategic Management Journal, v. 22, p. 1-23, 2001.

BRITO, L. A. L.; VASCONCELOS, F. C. How much does country matter? ENCONTRO ANUAL DA ANPAD, 27., 2003, São Paulo Anais... São Paulo: ANPAD, 2003.

BRUSH, T.H.; BROMILEY, P. What does a small corporate effect mean? A variance components simulation of corporate and business effects. Strategic Management Journal, v. 18, p. 825-835, 1997.

BRUSH, T. H.; BROMILEY, P.; HENDRICKX, M. The relative influence of industry and corporation on business segment performance: an alternative estimate. Strategic Management Journal, v. 20, p. $519-547,1999$.

CARROLL, G.R. A sociological view on why firms differ. Strategic Management Journal, v. 14, p. $237-249,1993$.

CHANG, S.; SINGH, H. Corporate and industry effects on business unit competitive position. Strategic Management Journal, v. 21, p.739 - 752, 2000.

CLAVER, E.; MOLINA, J.; TARÍ, J. Firm and industry effects on firm profitability: a Spanish empirical analysis. European Management Journal, v. 20, n. 3, p. 321-328, 2002.

COOL, K.; COSTA, L. A.; DIERICKX, I.. Constructing competitive advantage. In: PETTIGREW, A.; THOMAS, H.; WHITTINGTON, R. Handbook of Strategic Management. London: Sage Publications, 2002.

CONNER, K. R. A historical comparison of resource-based theory and five schools of thought within industrial organization economics: do we have a new theory of the firm? Journal of Management, $v$. 17, n. 1, p. 121-154, 1991.

HANSEN, G. S.; WERNERFELT, B. Determinants of firm performance: The relative importance of economic and organizational factors. Strategic Management Journal, v. 10, p. 399 - 411, 1989.

HAWAWINI, G.; SUBRAMANIAN, V.; VERDIN, P. Is performance driven by industry - or firmspecific factors? A new look at the evidence. Strategic Management Journal, v. 24, p. 1-16. 2003.

HOSKISSON, R. Theory and research in strategic management: swings of a pendulum. Journal of Management (Yearly Review of Management), May-June, 1999.

KHANNA, T.; RIVKIN, J.W. Estimating the performance effects of business groups in emerging markets. Strategic Management Journal, v. 22, p. 45 - 74, 2001.

KLEIN, K. J.; DANSEREAU, F.; HALL, R. J. Level issues in theory development, data collection, and analysis. Academy of Management Review, v. 19, p. 195-229, 1994.

MAURI, A. J.; MICHAELS, M. P. Firm and industry effects within strategic management: An empirical examination. Strategic Management Journal, v. 19, p. 211 - 219, 1998.

McGAHAN, A. M. The performance of US corporations: 1981 - 1994. The Journal of Industrial Economics, v. XLVII, n. 4, p. 373 - 398, 1999.

McGAHAN, A. M; PORTER, M. E. How much does industry matter, really? Strategic Management Journal, v. 18, summer special issue, p. 15-30, 1997. 
McGAHAN, A. M; PORTER, M. E. The persistence of shocks to profitability. The Review of Economics and Statistics, v. 81, n. 1, p. $143-153,1999$.

McGAHAN, A. M; PORTER, M. E. What do we know about variance in accounting profitability? Management Science, v. 48, p. 834-851, 2002.

McNAMARA, G.; VAALER, P. M.; DEVERS, C. Same as it ever was: the search for evidence of increasing hypercompetition. Strategic Management Journal, v. 24, p. 261-278, 2003.

NELSON, R. R. Why do firms differ, and how does it matter? Strategic Management Journal, v. 12, p. $61-74,1991$.

PENROSE, E. The Theory of the Growth of the Firm. New York, John Wiley, 1959.

PETERAF, M. A. The cornerstones of competitive advantage: a resource-based view. Strategic Management Journal, v. 14, p. 179-191, 1993.

PORTER, M. E. The contributions of industrial organization to strategic management. Academy of Management Review, v. 6, p. $609-620,1981$.

POWELL, T. C. How much does industry matter? An alternative empirical test. Strategic Management Journal, v. 17, p. 323 - 334, 1996.

RAVENSCRAFT, D. J. Structure-profit relationship at the line of business and industry level. The Review of Economics and Statistics, v. 65, p. 22-31, 1983.

ROQUEBERT, J. A.; PHILLIPS, R. L.; WESTFALL, P. A. Markets vs. management: what drives profitability? Strategic Management Journal, v. 17, p. 653-664, 1996.

RUEFLI, T.W.; WIGGINS, R.R. Industry, corporate and segment effects and business performance: a non-parametric approach. Strategic Management Journal,v. 24, p. 861 - 879, 2003.

RUMELT, R. P. How much does industry matter? Strategic Management Journal, v. 12, p. 167-185, 1991.

SCHMALENSEE, R. Do markets differ much? The American Economic Review, v. 75, n. 3, p. 341$351,1985$.

SEARLE, S.R.; CASELLA, G.; McCULLOCH, C.E. Variance components. New York, John Wiley \& Sons Inc, 1992.

SELZNICK, P. Leadership and Administration. New York, Harper \& Row, 1957.

SLACK, N.; LEWIS, M. Operations strategy. New York, Prentice-Hall, 2001.

SPANOS, A. Probability theory and statistical inference: econometric modeling with observational data. Cambridge, Cambridge University Press, 1999.

WALKER, G. Modern Competitive Strategy. Boston: McGraw-Hill Irwin, 2004.

WERNERFELT, B. A resource-based view of the firm. Strategic Management Journal, v. 5, p. 171$180,1984$.

WERNERFELT, B. The resource-based view of the firm: Ten years after. Strategic Management Journal, v.16, p. 171- 174, 1995. 
WERNERFELT, B.; MONTGOMERY, C.A. Tobin's $\mathrm{q}$ and the importance of focus in firm performance. The American Economic Review, v. 78, p. 246 - 250, 1988. 